\title{
EXISTE UM DIREITO AO ESQUECIMENTO? UMA ANÁLISE DA DECISÃO DO STF NO JULGAMENTO DO RECURSO EXTRAORDINÁRIO 1010606
}

\author{
Maria Vital da Rocha ${ }^{1}$ \\ Lidiane Moura Lopes ${ }^{2}$
}

\section{RESUMO}

O presente artigo tem como objeto de investigação a análise fática e legal acerca da existência de um direito ao esquecimento. Discute-se a importância do tema com fulcro na relevância dos direitos da personalidade, notadamente, aqueles que encontrando assento constitucional pautam-se no resguardo da intimidade e privacidade, sempre com a preocupação voltada para a manutenção do princípio da dignidade humana, fundamento de todo o sistema. O ponto culminante do texto é o entendimento do Supremo Tribunal Federal que no julgamento do Recurso Extraordinário 1010606 decidiu pela sua inexistência como direito no Brasil.

PALAVRAS-CHAVE: A importância da reconstrução da memória; Direito ao esquecimento; Direitos da Personalidade; O STF e o Recurso Extraordinário 1010606; Segurança Jurídica.

\section{IS THERE A RIGHT TO FORGETTING? AN ANALYSIS OF THE STF DECISION IN THE JUDGMENT OF THE EXTRAORDINARY APPEAL 1010606}

\begin{abstract}
This article aims to investigate the factual and legal analysis of the existence of a right to be forgotten. It discusses the importance of the theme with a focus on the relevance of personality rights, notably, those who find a constitutional seat are guided by the protection of intimacy and privacy, always with the concern focused on the maintenance of the principle of human dignity, the foundation of all the system. The culminating point of the text is the understanding of the Supreme Federal Court, which, in the judgment of Extraordinary Appeal 1010606, decided that it did not exist as a right in Brazil.

KEY WORDS: The importance of memory reconstruction. Right to be forgotten. Personality Rights. STF and Extraordinary Appeal 1010606. Legal Security.
\end{abstract}

\section{Introdução}

\footnotetext{
${ }^{1}$ Pós Doutoranda em Direito, na Faculdade de Direito da Universidade de Lisboa (clássica). Doutorado em Direito Civil pela Universidade de São Paulo. Professora Adjunta de Direito Civil, na Faculdade de Direito da Universidade Federal do Ceará, lecionando na graduação e no programa de pós graduação stricto sensu, é Professora Titular do Curso de Direito do Centro Universitário 7 de Setembro - UNI7, lecionando na graduação e no mestrado. Procuradora Federal aposentada. Contato: mavital@ secrel.com.br.

${ }^{2}$ Advogada. Pós Doutorando em Direito do Mar pela Escola de Guerra Naval da Marinha do Brasil. Doutora em Direito e Ordem Constitucional pela Universidade Federal do Ceará - UFC. Mestra em Direito pela Universidade Federal do Pará. Professora Universitária no Centro Universitário Estácio do Ceará, lecionando nos cursos de graduação e pós-graduação. Contato: lidimlopes@ hotmail.com.
} 
O estudo do direito ao esquecimento reveste-se de especial importância na sociedade da informação que ora busca-se estabelecer nos dias hodiernos. Neste sentido, há uma incessante corrida por notícias e fatos, cujos conteúdos nem sempre transmudam-se de primário interesse público.

Há por outro lado, a necessidade da preservação da memória como forma de resgate da história, sem perder de vista que tais dados históricos precisam ser criticamente entendidos na medida que contribuem para a formação da sociedade e neste ínterim, pergunta-se: existiria de fato um direito ao esquecimento que poderia ser oponível erga omnes?

Para responder à indagação acima, o ponto central é a decisão do Supremo Tribunal Federal no julgamento do Recurso Extraordinário 101606, que foi antecedida de outros posicionamentos esboçados pelo Superior Tribunal de Justiça, e que deve ser entendida nos termos em que proferida, mas que com certeza terá relevância na medida em que constitui-se em julgado paradigma para casos futuros.

Quanto à metodologia adotada primou-se pela escolha do método hipotético com ampla revisão das fontes bibliográficas nacionais e estrangeiras acerca do assunto, com o estudo de temas mais amplos como a formação da memória coletiva e suas implicações na reconstrução dos fatos sociais que serão apresentados às gerações vindouras e que só será possível com o exercício da liberdade de informar.

\section{A importância da preservação da memória}

Alberto Caeiro da Silva, um dos autores fictícios criados pelo escritor português Fernando Pessoa ${ }^{3}$, chama a atenção pela passagem de "Poemas inconjuntos" na qual se reporta "se, depois de eu morrer, quiserem escrever a minha biografia, Não há nada mais simples. Tem só duas datas - a da minha nascença e a da minha morte. Entre uma e outra cousa todos os dias são meus" $"$.

\footnotetext{
${ }^{3}$ Que criou outros personagens a exemplo de Álvaro de Campos, um dos seus mais famosos, cujas obras creditadas incluem: Passagem das Horas (1916), Apontamento (1929), Tabacaria (1929), Magnificat (1933), Aniversário (1930), Lisbon Revisited (1923), entre outras.

${ }^{4}$ Disponível em: http://www.dominiopublico.gov.br/download/texto/pe000003.pdf. Acesso em: 18.03.2021.
} 
O trecho acima chama a atenção para a importância que representa a recontagem da história, dos fatos, da vida das pessoas que acabam por se constituir na memória que se busca preservar para as gerações vindouras.

Observa Michael Pollak que "a clivagem entre memória oficial e dominante e memórias subterrâneas, assim como a significação do silêncio sobre o passado, não remete forçosamente à oposição entre Estado dominador e sociedade civil” (1989. p. 3). O autor prossegue exemplificando que em algumas situações a verdade "velada" pode se constituir em um mecanismo de defesa, tal qual entende aconteceu com os judeus após o retorno dos campos de concentração, como uma forma de se resguardar de um passado que poderia comprometer o seu futuro e acentua que "essa atitude é ainda reforçada pelo sentimento de culpa que as próprias vítimas podem ter, oculto no fundo de si mesmas". (POLLAK, 1989, p. $3)$.

Hoje a preservação da memória através da recontagem dos fatos torna-se mais fácil diante das possibilidades tecnológicas de sua manutenção, incluindo a reprodução em tempo real do ocorrido. É o passado que constrói a história do presente. A reconstrução dos fatos torna o homem um ser inserido num contexto que o possibilita ditar os rumos do futuro, com repetições ou correções.

Não há cultura sem passado, por ser da essência a apropriação das formas de pensar e agir em dado momento. Eis a importância dos fatos que não pode ser ignorada. E diante das inovações que a tecnologia trouxe conclui-se que "hoje todos influenciam e são influenciados. Há interações em rede, velozes e simultâneas” (FARIAS; BRAGA NETTO, ROSENVALD, 2017, p. 229).

Por outro lado, a era que vivemos orientada por um "superinformacionismo", requer cuidado na propagação indiscriminada de fatos que sem qualquer conteúdo de interesse público, pode vir a causar a exposição desnecessária de pessoas que tiveram suas histórias marcadas por fatos controvertidos, sejam quanto aos aspectos morais, levando em consideração a média da sociedade, ou até mesmo criminalmente comprometedores.

2.1 Breve análise do conteúdo de um direito ao esquecimento: um pouco da origem 
No julgamento do Recurso Extraordinário (RE) 1010606 que deu origem à pesquisa, o Supremo Tribunal Federal lembrou que a origem da discussão acerca de um direito ao esquecimento remonta à década de 60 quando o professor Gerard Lyon-Caen, utilizou a expressão francesa "le droit à l'oubli" ao comentar da decisão exarada no caso "l'affaire Landru”, julgado pela Corte de Apelação de Paris, em 1967. Reporta que no caso

[...] a ex-amante (Mme. S.) do Serial Killer Henri Landru, que estava a seu lado quando ele foi preso, propôs ação de indenização em face de diretor de cinema, de produtora e de distribuidora parisienses em função da produção de um documentário ficcional que apresentava trechos de sua vida ao lado do serial killer, com a utilização de seu nome sem sua autorização ${ }^{5}$.

Interessante observar que o professor parisiense preferiu a expressão "direito ao esquecimento" (o direito de ser esquecido - em livre tradução da expressão: "le droit à l'oubli") à "la prescription du silence" (que se referia a ideia de uma "prescrição do silêncio") que em apetada síntese refere-se à "prescrição de fatos que já não são relevantes".

Ousa-se apontar, que a demanda não fora aceita nos termos em que proposta, mas sim em razão da Corte francesa ter vislumbrado a ocorrência do crime de "atentado violento ao

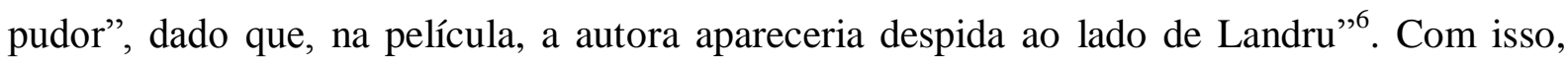
percebe-se que já naquele momento esboçava-se a necessidade de construção de decisões casuísticas.

Foi em 1983 que o Tribunal de Grande Instance de Paris reportou-se expressamente à expressão "droit à l'oubli” que de acordo com dados extraídos do próprio julgado do STF no voto do Ministro Dias Toffoli, o caso tratou da

[...] divulgação pela revista semanal Paris Match da fotografia de uma mulher como sendo assassina da esposa e do filho de seu amante. Na fundamentação do julgado, o Tribunal, a par de não admitir a exceção da verdade, considerou atentado à honra a publicação da fotografia e o uso indevido da imagem (visto que sem autorização da

\footnotetext{
${ }^{5}$ Disponível em: http://www.stf.jus.br/arquivo/cms/noticiaNoticiaStf/anexo/RE1010606VOTOMDT.pdf Acesso em 26.03.2021.

${ }^{6}$ Disponível em: http://www.stf.jus.br/arquivo/cms/noticiaNoticiaStf/anexo/RE1010606VOTOMDT.pdf Acesso em 26.03.2021. Em termos fáticos, a Corte de Apelação de Paris ressaltou que não é reconhecido um direito ao esquecimento "de alguém que foi a amante de um criminoso célebre, quando essa pessoa havia anteriormente, por diversas vezes, tentado publicar suas memórias, o que prova que ela não aspirava que se fizesse silêncio sobre esse período da sua existência". Extraído do site: http://www.stf.jus.br/arquivo/cms/noticiaNoticiaStf/anexo/RE1010606VOTOMDT.pdf Acesso em 26.03.2021.
} 
retratada), além de não ter vislumbrado correlação entre a divulgação e qualquer informação a ela contemporânea ou fato histórico ${ }^{7}$.

Percebe-se, portanto, que ao longo do tempo o "direito de não ser lembrado" ou de simplesmente "ser esquecido" trouxe discussões importantes. O estudo dos casos ocorridos na França mostra que houve uma certa resistência ao reconhecimento do direito ao esquecimento ou como preferiram os franceses, de um direito à prescrição do silêncio.

Não é em outro sentido que ao decidir o caso Madame Monanges contra Kern et Marque-Maillard, a Corte de Cassação da França afasta novamente a existência de um direito ao esquecimento ${ }^{8}$, concluindo o Ministro Dias Toffoli ao analisar tais casos que "embora exista um dever de prudência do autor quanto ao relato dos fatos, não há atentado à vida privada em publicações licitamente obtidas por debates judiciários ou relatos da imprensa, inexistindo em tais casos direito ao esquecimento"

Em síntese, o direito ao esquecimento comportaria como conteúdo a objeção à lembrança, ou seja

[...] o direito de não ser citado no corpo de um relato atual sobre eventos pretéritos de caráter público; é o direito de não ser lembrado, de não ter uma passagem ruim da vida - outrora legitimamente tornada pública por sua conexão com fatos terríveis recontada agora, tantos anos depois, apesar da sua veracidade e desde que a evocação da história se mostre nociva à vida da pessoa implicada ${ }^{10}$.

O próprio Supremo Tribunal Federal na decisão que deu ensejo ao presente artigo reconheceu a dificuldade em preencher o conceito de direito ao esquecimento entendendo-o como "essencialmente multifário[...]. Trata-se, em verdade, de um conceito guarda-chuva que

\footnotetext{
${ }^{7}$ http://www.stf.jus.br/arquivo/cms/noticiaNoticiaStf/anexo/RE1010606VOTOMDT.pdf Acesso em 26.03.2021.

8 Interessante reproduzir no voto do Ministro Dias Toffoli a história do caso, ao observar que trata-se de uma publicação, datada de 1986, "do livro Um toboggan dans la tourmente, 1940-1945 - de autoria de um resistente da ocupação nazista na França (Kern), no qual discorria, entre outras coisas, sobre julgamento e condenação do colaboracionista Chatelat e de sua amante Madame Monanges (1946) -, sofreu o autor da obra ação proposta por essa última, com fundamento na violação da sua vida privada". Disponível em: http://www.stf.jus.br/arquivo/cms/noticiaNoticiaStf/anexo/RE1010606VOTOMDT.pdf Acesso em 26.03.2021.

${ }^{9}$ Disponível em: http://www.stf.jus.br/arquivo/cms/noticiaNoticiaStf/anexo/RE1010606VOTOMDT.pdf Acesso em 26.03.2021.

${ }^{10}$ Disponível em: http://www.stf.jus.br/arquivo/cms/noticiaNoticiaStf/anexo/RE1010606VOTOMDT.pdf Acesso em 26.03.2021. Trecho extraído de: MARTINS NETO, João dos Passos; PINHEIRO, Denise, Liberdade de Informar e Direito à Memória - Uma crítica à ideia do direito ao esquecimento. Disponível no endereço eletrônico: https://siaiap32.univali.br/seer/index.php/nej/article/view/6670. Acesso em 26.03.2021.
} 
recolhe uma pluralidade de direitos singulares que, não necessariamente, se adunam"11. Eis, alguns dos desafios que o direito enfrenta na tentativa de solução dos problemas que se colocam quando se pretende que a liberdade de expressão ceda em nome do interesse privado.

2.2 Direito ao esquecimento: um diálogo com os direitos da personalidade

Interessante observar que as discussões sobre o direito ao esquecimento nascem lastreadas pelas indagações acerca dos limites do direito à privacidade e intimidade. Diante disso, optamos por entender como a intimidade e a privacidade são delineadas como reflexos dos direitos da personalidade, sem descuidar da sua recepção como uma garantia constitucional.

O tema precisa ser cotejado ainda com o direito à informação estabelecendo uma ponte necessária com o exercício da liberdade de expressão e, por consequência, de imprensa e uma possível censura diante da ponderação do caso concreto. Eis, portanto, o multifacetário sistema no qual se encontra entrelaçado, desafiante e em construção, instigando a procura por saídas e não soluções que deverão passar por uma análise sempre casuística.

$\mathrm{Na}$ Alemanha o direito ao esquecimento foi sopesado com outros direitos que diante de uma ponderação no caso concreto, fez a Corte Constitucional Alemã decidir que

[...] do embate entre a proteção da personalidade e a liberdade de informar por meio de radiodifusão, ainda que este direito tenha uma precedência geral no que tange à informação sobre atos criminosos, na hipótese, deveria prevalecer a proteção da personalidade e a consequente proibição de exibição documentário, já que não mais havia interesse atual na retomada do assunto e por afetar à ressocialização do autor $^{12}$.

Interessante observar que a pretensão de reconhecimento de um direito ao esquecimento cinge-se à esfera individual, com intenção de justificar-se no princípio maior da dignidade da pessoa humana e no arcabouço de direitos que o acompanham. Entre os

\footnotetext{
${ }^{11}$ Disponível em: https://www.conjur.com.br/dl/voto-fachin1.pdf. Acesso em: 20.03.2021.

12 Disponível em: http://www.stf.jus.br/arquivo/cms/noticiaNoticiaStf/anexo/RE1010606VOTOMDT.pdf Acesso em 26.03.2021. Trecho extraído de: MARTINS NETO, João dos Passos; PINHEIRO, Denise, Liberdade de Informar e Direito à Memória - Uma crítica à ideia do direito ao esquecimento. Disponível no endereço eletrônico: https://siaiap32.univali.br/seer/index.php/nej/article/view/6670. Acesso em 26.03.2021.
} 
constitucionalista há uma importante discussão sobre a existência ou de direitos fundamentais de natureza absoluta.

Como o reconhecimento de um direito ao esquecimento depende da interpretação que será dada no caso, acerca de quais valores serão preponderantes, o embate sobre uma relatividade ou não de todos os direitos fundamentais acaba por justificar-se e é o que será resumidamente feito. Ao estudar a proibição da tortura e de outros tratamento desumanos e degradantes vedados pelo texto constitucional, há quem defenda que

[...] não é de se admitir o recurso à ponderação de bens, e, portanto, a utilização da proporcionalidade, para, no conflito entre a proibição da tortura e de tratamentos desumanos e degradantes e outros direitos fundamentais e bens constitucionalmente assegurados, admitir eventual relativização de tal proibição, pois esta assume caráter absoluto [...] (SARLET; MARINONI; MITIDIERO, 2017, p. 426).

Virgílio Afonso da Silva no mesmo sentido dos autores citados acima também defende a existência de direitos de natureza absoluta e diz que seria intuitivo supor que o STF está certo quando decide pela inexistência de direitos absolutos, mas conclui que esta ideia é equivocada e cita além da proibição da tortura a vedação de extradição do brasileiro nato (2021, p. 117). E traz a colação a seguinte decisão proferida no Habeas Corpus 831133 (Questão de Ordem) que teve como ministro relator Celso de Mello

\begin{abstract}
O brasileiro nato, quaisquer que sejam as circunstâncias e a natureza do delito, não pode ser extraditado, pelo Brasil, a pedido de Governo estrangeiro, pois a Constituição da República, em cláusula que não comporta exceção, impede, em caráter absoluto, a efetivação da entrega extradicional daquele que é titular, seja pelo critério do jus soli, seja pelo critério do jus sanguinis, de nacionalidade brasileira primária ou originária ${ }^{13}$.
\end{abstract}

Há ainda um outro movimento que é o de constitucionalização do direito civil e leva em seu bojo os direitos da personalidade, trata-se não de mera retórica, mas de situações com repercussões de ordem prática, a ensejar a depender do centro das discussões do direito ao esquecimento a interposição do Recurso Especial para o Superior Tribunal de Justiça ou o Recurso Extraordinário para o Supremo Tribunal Federal ${ }^{14}$.

\footnotetext{
${ }^{13}$ Disponível em: http://www.stf.jus.br/portal/constituicao/artigobd.asp?item=\%20188. Acesso em 03.04.2021.

${ }^{14}$ Tal fato já fora reconhecido pelo STJ ao estabelecer que "[...]no julgamento do REsp. n. 1.183.378/RS, que, depois da publicização do direito privado, vive-se a chamada constitucionalização do direito civil, momento em
} 
Há que se conceber ainda que num Estado Democrático de Direito como pretende ser o nosso, o direito de informar e de ser informado constitui-se em condição sine qua para o exercício das demais liberdades, incluindo os atos de fiscalização por parte dos cidadãos das tomadas de decisões públicas.

É dessa forma, portanto, que a liberdade de expressão e o direito à informação acabam por chocar-se com o resguardo da privacidade, prevendo o próprio Código Civil no artigo 20 que

\begin{abstract}
Salvo se autorizadas, ou se necessárias à administração da justiça ou à manutenção da ordem pública, a divulgação de escritos, a transmissão da palavra, ou a publicação, a exposição ou a utilização da imagem de uma pessoa poderão ser proibidas, a seu requerimento e sem prejuízo da indenização que couber, se the atingirem a honra, a boa fama ou a respeitabilidade, ou se se destinarem a fins comerciais. (Grifo nosso)
\end{abstract}

Não em outro sentido, observa-se que há por parte do legislador civil uma omissão relevante no dispositivo citado, pois ao valorizar a intimidade esquece-se do relevante papel desempenhado pela informação, o que é chancelado pela doutrina civilista reconhecendo "a função social da livre circulação das informações" (FARIAS; BRAGA NETTO, ROSENVALD, 2017, p. 229).

\title{
30 direito ao esquecimento no Brasil: considerações preliminares e o posicionamento do Superior Tribunal de Justiça
}

Como se trata de um instituto que não encontra previsão legal as controvérsias que gravitam em torno do reconhecimento de um direito ao esquecimento no Brasil tornam-se ainda mais instigantes.

Como se proteger da lembrança de um fato verdadeiro, cujo passado traz perturbações presentes na vida dos envolvidos? Ademais, a própria "verdade" do fato, com os seus limites

que o foco transmudou-se definitivamente do Código Civil para a própria Constituição Federal, de modo que os princípios constitucionais alusivos a institutos típicos de direito privado (como família e propriedade) passaram a condicionar a própria interpretação da legislação infraconstitucional [...] Superior Tribunal de Justiça, cumprindo sua missão de uniformizar o direito infraconstitucional, não pode conferir à lei uma interpretação que não seja constitucionalmente aceita (REsp 1.183.378/RS, Rel. Ministro LUIS FELIPE SALOMÃO, QUARTA TURMA, julgado em 25/10/2011). Disponível em: https://www.conjur.com.br/dl/direito-esquecimento-acordaostj.pdf. Acesso em: 28.03.2021. 
que o tempo impõe acaba por constituir-se em outro entrave na reconstituição que se pretenda apresentar no presente.

A questão torna-se mais eloquente quando se tem um texto constitucional que confere relevo à liberdade de expressão como uma garantia cujos limites não se reconhece num prévio juízo de censura. Pense-se ainda que o fato do passado, além de verdadeiro, foi licitamente divulgado na ocasião, portanto, por que o tempo tornaria ilícita a sua lembrança?

Numa visão mais prática, o próprio Superior Tribunal de Justiça, numa decisão que será mais adiante analisada, através do seu relator, ministro Villas Bôas Cueva, destacou a dificuldade em analisar casos envolvendo a discussão quanto à existência de um pretenso direito ao esquecimento, ponderando que a doutrina discute duas das suas principais acepções, quais sejam: "o direito ao esquecimento concebido a partir da ótica da proteção de dados pessoais e a configuração desse direito quando houver manifesta violação de direitos fundamentais" $" 15$.

Interessante reflexão é feita em artigo especializado sobre o assunto quando os autores observam que "é plausível sustentar a existência do direito de viver no isolamento, mas não do direito de ser esquecido, pois isto implicaria, para a mídia, a absurda obrigação de ocultar uma parte dos fatos e da verdade em narrativas históricas" ${ }^{\text {16 }}$. Ou seja, ao indivíduo é dada a opção de viver de forma reclusa, conforme seus interesses, mas isto não pode impedir que os fatos públicos decorrentes de sua existência sejam conhecidos pelos demais, nos limites do respeito à sua dignidade.

Em data mais longínqua o Superior Tribunal de Justiça (STJ) foi levado a se manifestar sobre o direito ao esquecimento quando analisou o Recurso Especial $\mathrm{n}^{\circ}$ 1.334.097 RJ (2012/0144910-7) originado de uma ação de reparação de danos morais ajuizada contra a TV Globo Ltda (Globo Comunicações e Participações S/A) por Jurandir Gomes de França. O caso resume-se ao fato de que o autor foi indiciado como um dos coautores dos homicídios ocorridos na porta da Igreja da Candelária, no Rio de Janeiro, na data de 23 de julho de 1993,

15 Disponível em: https://www.stj.jus.br/sites/portalp/Paginas/Comunicacao/Noticias/Para-Terceira-Turma-direito-ao-esquecimento-nao-pode-impedir-publicacoes-sobre-crime-de-repercussao.aspx. $\quad$ Acesso em: 28.03.2021.

${ }^{16}$ MARTINS NETO, João dos Passos; PINHEIRO, Denise. LIBERDADE DE INFORMAR E DIREITO À MEMÓRIA - uma crítica à ideia do direito ao esquecimento. Disponível em: file:///C:/Users/lidim/Downloads/6670-18054-1-SM.pdf. Acesso em: 27.03.2021. 
cujos fatos ganharam repercussão, inclusive internacional, ficando conhecidos como a "Chacina da Candelária"17.

Ocorre que Jurandir Gomes de França foi levado à Júri Popular e neste restou absolvido pela tese de negativa de autoria, sendo tal decisão tomada por unanimidade pelos membros do Conselho de Sentença. Após estes fatos, a TV Globo Ltda o procurou com o intuito de entrevistá-lo para o programa "Linha Direta - Justiça", convite que fora recusado, mas que posteriormente e sem a sua autorização, a referida emissora acabou apresentando um programa dedicado ao caso, mencionando a sua participação. Diante disso, Jurandir Gomes de França entendeu que

[...] levou-se a público situação que já havia superado, reacendendo na comunidade onde reside a imagem de chacinador e o ódio social, ferindo, assim, seu direito à paz, anonimato e privacidade pessoal, com prejuízos diretos também a seus familiares. Alega que essa situação lhe prejudicou sobremaneira em sua vida profissional, não tendo mais conseguido emprego, além de ter sido obrigado a desfazer-se de todos os seus bens e abandonar a comunidade para não ser morto por "justiceiros" e traficantes e também para proteger a segurança de seus familiares ${ }^{18}$.

Em primeira instância o pleito indenizatório fora negado pelo Juízo de Direito da $3^{\mathrm{a}}$ Vara Cível da Comarca da Capital/RJ que sopesando os interesses envolvidos concedeu primazia ao interesse público na narrativa deste "evento traumático da história nacional"19. $\mathrm{O}$ autor recorreu e teve a decisão revista ao decidir que

[...] se o autor, antes réu, viu-se envolvido em caráter meramente lateral e acessório, em processo do qual foi absolvido, e se após este voltou ao anonimato, e ainda sendo possível contar a estória da Chacina da Candelária sem a menção de seu nome, constitui abuso do direito de informar e violação da imagem do cidadão a edição de programa jornalístico contra a vontade expressamente manifestada de quem deseja prosseguir no esquecimento ${ }^{20}$.

Em sua defesa, a TV Globo Ltda alegou

\footnotetext{
${ }^{17}$ Informações disponíveis em: https://www.conjur.com.br/dl/direito-esquecimento-acordao-stj.pdf. Acesso em: 25.03.2021.

${ }^{18}$ Informações disponíveis em: https://www.conjur.com.br/dl/direito-esquecimento-acordao-stj.pdf. Acesso em: 25.03.2021.

${ }^{19}$ Informações disponíveis em: https://www.conjur.com.br/dl/direito-esquecimento-acordao-stj.pdf. Acesso em: 25.03.2021.

${ }^{20}$ Informações disponíveis em: https://www.conjur.com.br/dl/direito-esquecimento-acordao-stj.pdf. Acesso em: 25.03.2021.
} 
[...] não ter havido nenhuma invasão à privacidade/intimidade do autor, porque os fatos noticiados já eram públicos e fartamente discutidos na sociedade, fazendo parte do acervo histórico do povo. Argumenta que se tratou de programa jornalístico, sob forma de documentário, acerca de acontecimento de relevante interesse público, tendo a emissora se limitado a narrar os fatos tais como ocorridos, sem dirigir nenhuma ofensa à pessoa do autor, ao contrário, deixando claro que teria sido inocentado $^{21}$.

É claro no embate travado a discussão sobre a preponderância dos direitos da personalidade que se mostram em colisão diante da análise acerca da exposição dos fatos. Interessante que o autor alegou que tal exposição comprometera a sua felicidade e paz alastrando seus efeitos nefastos aos familiares e pessoas próximas.

No julgamento do referido recurso, o Ministro Luis Felipe Salomão inicia elencando os direitos conflituosos envolvidos

É inegável que o conflito aparente entre a liberdade de expressão/informação, ora materializada na liberdade de imprensa, e atributos individuais da pessoa humana como intimidade, privacidade e honra -, possui estatura constitucional (art. $5^{\circ}$, incisos IV, V, IX, X e XIV, arts. 220 e 221 da Constituição Federal), não sendo raras as decisões apoiadas predominantemente no cotejo hermenêutico entre os valores constitucionais em confronto ${ }^{22}$.

Há ainda que se recordar a existência do Enunciado n 531 aprovado na VI Jornada de Direito Civil promovida pelo CJF/STJ assegurando que "a tutela da dignidade da pessoa humana na sociedade da informação inclui o direito ao esquecimento". No entanto, quando da sua aprovação o desembargador do Tribunal Regional Federal da $5^{\text {a }}$ Região, Rogério Fialho Moreira, coordenador da Comissão de Trabalho da Parte Geral na VI Jornada ponderou que

[...] o enunciado garante apenas a possibilidade de discutir o uso que é dado aos eventos pretéritos nos meios de comunicação social, sobretudo nos meios eletrônicos. De acordo com ele, na fundamentação do enunciado ficou claro que o direito ao esquecimento não atribui a ninguém o direito de apagar fatos passados ou reescrever a própria história ${ }^{23}$.

\footnotetext{
${ }^{21}$ Informações disponíveis em: https://www.conjur.com.br/dl/direito-esquecimento-acordao-stj.pdf. Acesso em: 25.03.2021.

${ }^{22}$ Informações disponíveis em: https://www.conjur.com.br/dl/direito-esquecimento-acordao-stj.pdf. Acesso em: 25.03.2021.

${ }^{23}$ Disponível em: https://www.cjf.jus.br/cjf/noticias/2013/abril/enunciado-trata-do-direito-ao-esquecimento-nasociedade-dainformacao\#: :text=0\%20Enunciado\%20531\%20diz\%20que, \%C3\%A0\%20dignidade\%20da\%20pessoa\%20hu mana. Acesso em 20.03.2021.
} 
O enunciado acima citado refere-se ao artigo 11 do Código $\mathrm{Civil}^{24}$ e na sua justificativa recebeu a seguinte consideração de que não se trata de atribuir um direito de apagar fatos pretéritos, tampouco de reescrever a própria história, "mas apenas assegura a possibilidade de discutir o uso que é dado aos fatos pretéritos, mais especificamente o modo e a finalidade com que são lembrados $25 \%$.

Em notícia mais recente relacionada a processo cujo número do Recurso Especial não fora revelado em razão do segredo de justiça, o STJ entendeu pela não aplicação da tese do direito ao esquecimento "para impedir a publicação futura de reportagens sobre um crime ou sobre as pessoas condenadas por ele, pois isso configuraria censura prévia - mais ainda em caso que teve ampla repercussão na sociedade" 26 .

O caso envolveu uma pessoa que já havia cumprido pena há mais de 30 anos e que pleiteou pela impossibilidade de divulgação de tal fato pretérito e desabonador. $\mathrm{Na}$ ação o autor alegou a "exposição sensacionalista da pessoa e de seus familiares, inclusive com a publicação de fotos sem autorização. Em primeira e segunda instâncias, a editora foi condenada a indenizar os danos morais" ${ }^{, 27}$. A segunda instância também confirmou a condenação.

Entretanto, o relator do processo no STJ, manifestou-se pelo não acolhimento da tese "para o fim de proibir qualquer veiculação futura de matérias jornalísticas relacionadas ao fato criminoso, sob pena de configuração de censura prévia, vedada pelo ordenamento jurídico pátrio" ${ }^{28}$. Trata-se de uma decisão veiculada no site do Tribunal Superior de Justiça no ano de 2020, portanto, recente e que muda o posicionamento esboçado pela Corte no julgamento anteriormente mencionado.

\footnotetext{
${ }^{24}$ Código Civil. Art. 11. Com exceção dos casos previstos em lei, os direitos da personalidade são intransmissíveis e irrenunciáveis, não podendo o seu exercício sofrer limitação voluntária.

${ }^{25}$ Disponível em: https://www.cjf.jus.br/enunciados/enunciado/142. Acesso em: 22.03.2021.

26 Disponível em: https://www.stj.jus.br/sites/portalp/Paginas/Comunicacao/Noticias/Para-Terceira-Turma-direito-ao-esquecimento-nao-pode-impedir-publicacoes-sobre-crime-de-repercussao.aspx. $\quad$ Acesso em: 28.03.2021.

${ }^{27}$ Disponível em: https://www.stj.jus.br/sites/portalp/Paginas/Comunicacao/Noticias/Para-Terceira-Turma-direito-ao-esquecimento-nao-pode-impedir-publicacoes-sobre-crime-de-repercussao.aspx. Acesso em: 28.03.2021.

${ }^{28}$ Disponível em: https://www.stj.jus.br/sites/portalp/Paginas/Comunicacao/Noticias/Para-Terceira-Turma-direito-ao-esquecimento-nao-pode-impedir-publicacoes-sobre-crime-de-repercussao.aspx. Acesso em: 28.03.2021.
} 
Oportuno observar que o ministro relator ao entender pela improcedência do pedido pleiteado cotejou o direito ao esquecimento ao interesse público na historicidade dos fatos, reconhecendo ainda que "a liberdade de imprensa não tem caráter absoluto e encontra limite nos direitos da personalidade, notadamente no direito à imagem e à honra das pessoas sobre as quais se noticia",29.

Ademais entendeu que decidir de forma contrária caracterizaria um "apagamento de trecho significativo da história de crimes famosos que compõem a memória coletiva" ${ }^{30}$. A diferença deste último caso com o analisado anteriormente funda-se também no fato de que neste a pessoa sofrera de fato a condenação com trânsito em julgado, o que confere certeza ao fato criminoso exposto e não uma mera acusação.

3.1 Um olhar crítico da decisão do Supremo Tribunal Federal no julgamento do Recurso Extraordinário (RE) 101060

Antes de adentrar na análise do RE 101060, urge colocar que a relativização dos direitos fundamentais na ponderação com outras garantias é desenhada pelo STF desde o julgamento do Recurso Extraordinário (RE) 389.808, de relatoria do ministro Celso de Mello, julgado na data já distante de 16 de setembro de 1999 onde se defendeu que

\begin{abstract}
Os direitos e garantias individuais não têm caráter absoluto. Não há, no sistema constitucional brasileiro, direitos ou garantias que se revistam de caráter absoluto, mesmo porque razões de relevante interesse público ou exigências derivadas do princípio de convivência das liberdades legitimam, ainda que excepcionalmente, a adoção, por parte dos órgãos estatais, de medidas restritivas das prerrogativas individuais ou coletivas, desde que respeitados os termos estabelecidos pela própria Constituição ${ }^{31}$.
\end{abstract}

Mas a discussão sobre a existência de um direito ao esquecimento pelo STF ganhou relevância através da análise e julgamento do Recurso Extraordinário (RE) 101060, com

\footnotetext{
${ }^{29}$ Disponível em: https://www.sti.jus.br/sites/portalp/Paginas/Comunicacao/Noticias/Para-Terceira-Turma-direito-ao-esquecimento-nao-pode-impedir-publicacoes-sobre-crime-de-repercussao.aspx. Acesso em: 28.03.2021.

${ }^{30}$ Disponível em: https://www.stj.jus.br/sites/portalp/Paginas/Comunicacao/Noticias/Para-Terceira-Turma-direito-ao-esquecimento-nao-pode-impedir-publicacoes-sobre-crime-de-repercussao.aspx. Acesso em: 28.03.2021.

${ }^{31}$ Disponível em: http://www.stf.jus.br/portal/constituicao/artigoBd.asp?item=31. Acesso em 02.04.2021.
} 
repercussão geral reconhecida e cujas questões serão suscintamente apontadas nas linhas que seguem, a fim que de possamos extrair os fundamentos da decisão e suas possíveis repercussões no futuro.

O caso fático a amparar o recurso julgado pelo STF refere-se a um crime ocorrido no Rio de Janeiro, na década de 50, especificamente na data de 14 de julho de 1958, quando a jovem Aída Jacob Curi, filha de imigrantes sírios e contando com apenas 18 anos de idade, na noite do referido dia saiu de um curso de datilografia e encaminhava-se para a sua residência, quando teve o encontro fatídico que ceifaria a sua vida ${ }^{32}$.

Apesar do transcurso do tempo, o caso pela barbárie da história repercutiu nos anos vindouros e fez com que a rede Globo, em 2004, fizesse a reconstituição que foi levada ao público através do programa "Linha Direta"33.

\footnotetext{
${ }^{32}$ Disponível em: https://canalcienciascriminais.jusbrasil.com.br/noticias/203742780/o-direito-ao-esquecimentona-sociedade-da-informacao-o-caso-aida-curi. Acesso em 27.03.2021.

${ }^{33}$ Consta na internet informações detalhadas sobre o caso, incluindo a história pessoal da vítima, conforme se lê resumidamente e na íntegra que: "Nascida em Belo Horizonte, Aída Jacob Curi era a terceira dos cinco filhos do casal Gattas Assad Curi e Jamila Jacob Curi. Aos quatro anos, já orfã de pai, Aída se mudou com a mãe e os irmãos para Goiás e de lá para o Rio de Janeiro. No Rio, ela foi matriculada em um educandário, no bairro de São Cristóvão, destinado a meninas órfãs. Ela só sairia de lá 12 anos depois, para viver por apenas sete meses. Apesar de receber visitas da mãe, Aída praticamente não teve contato com o mundo exterior. Inocente, casta e religiosa, ela se tornou um alvo fácil para os rapazes da chamada "juventude transviada", que começava a despontar em Copacabana. Entre eles, o playboy Ronaldo Guilherme de Souza Castro, 19 anos. Aída conheceu Ronaldo, na tarde do dia 14 de julho de 1958, quando saía com uma amiga, Ione Arruda Gomes, de um curso de datilografia, em Copacabana. Bom de papo, Ronaldo conseguiu convencê-la a ir até a casa de um amigo, de onde ela teria a vista mais bonita da praia. Como o amigo não estava em casa, eles desceram do prédio e seguiram pela rua Aires Saldanha, atrás da avenida Atlântica, onde encontraram o estudante Manoel Antônio da Silva Costa. Ronaldo se afastou da moça e perguntou a Manoel por Cácio Murilo Ferreira da Silva, enteado do síndico de um prédio próximo. Cácio costumava emprestar as chaves do terraço, para onde os rapazes levavam as meninas para namorar. Manoel fez o pedido a Cácio e ele concordou. Sem imaginar o que estava para acontecer, Aída subiu com Ronaldo pelo elevador social, mas desceu logo depois, porque as chaves que Cácio emprestara só davam acesso pelos fundos do edifício. Ao descer, o casal encontrou o rapaz no térreo. Cácio os levou até o $12^{\circ}$ andar e depois, por uma escada, até a cobertura. Logo depois, ele apagou o isqueiro, que usou para guiá-los pela cobertura escura, e fingiu descer. No entanto, o rapaz apertou o botão do elevador para o térreo e se escondeu num canto escuro para observá-los. A chegada do elevador ao térreo era a senha para que o porteiro Antônio João de Souza subisse à cobertura. Enquanto Aída se entretinha com a vista, Ronaldo tentou agarrá-la por trás. Ela resistiu, lutou e ele se tornou mais agressivo. Cácio e Antônio se aproximaram da menina e ajudaram Ronaldo a espancá-la, a rasgar sua saia e a tentar estuprá-la. Ela continuou lutando até desfalecer. Para simularem um suicídio e se livrarem da culpa, os três a colocaram sobre o parapeito da cobertura e a empurraram. O corpo de Aída chegou ao solo menos de três segundos depois. Após o crime, Ronaldo foi submetido a três julgamentos, até ter sua pena definitiva fixada em oito anos e nove meses de prisão por homicídio e tentativa de estupro. O porteiro Antônio foi absolvido após o segundo julgamento e fugiu. Cácio, que era menor de idade na época do crime, foi encaminhado ao Serviço de Assistência ao Menor. O assassinato de Aída Curi ficou marcado como o acontecimento que representou o fim da inocência do bairro de Copacabana". Disponível em: http://redeglobo.globo.com/Linhadireta/0,26665,GIJ0-5257-215780,00.html. Acesso em: 27.03.2021.
}

Revista Brasileira de Teoria Constitucional | e-ISSN: 2525-961X | Encontro Virtual | v. 7 | n. 1 | 
O caso chegou até o STF através da interposição do Recurso Extraordinário contra acórdão do Tribunal de Justiça do Estado do Rio de Janeiro que confirmou a improcedência da ação indenizatória (na ação os requerentes demandaram compensação pecuniária e reparação material, em desfavor da GLOBO COMUNICACAO E PARTICIPACOES S/A, em razão do uso não autorizado da imagem de sua falecida irmã). Neste sentido aduziram que

[...] o programa televisivo exibido pela recorrida revisitou eventos traumáticos ocorridos na década de 1950, explorando não apenas a dor se sua família, senão também imagens de sua irmã. Aduzem que a dor causada pelo revolvimento dos fatos foi recrudescida pela abordagem feita pelo programa. Em lugar de um tratamento jornalístico, teria sido empregado um viés cênico, sensacionalista e estritamente comercial, que explorou graficamente o conteúdo de violência do caso $^{34}$

A demandada alegou em seu favor que os dados veiculados no programa televisivo "foram, em larga medida, extraídos de arquivos públicos e bancos de reportagens disponíveis em bibliotecas e na internet" ${ }^{\prime 35}$. E esses acabam sendo os substratos fundamentais da própria decisão, pois há uma historicidade pública do fato, cuja condenação ao final não se confirmou, mas que nem por isso deixou de existir.

Vê-se, portanto, que a decisão do STF representa importante avanço na construção da memória e historicidade dos fatos, mas os limites que nortearão futuras construções acerca do assunto, dependerão dos fatos analisados e da preponderância que se dê aos direitos da personalidade ou ao interesse público no caso concreto.

3.2 A censura, a liberdade de expressão e o direito ao esquecimento: é possível conciliar?

Os limites da liberdade de expressão são variáveis de acordo com o contexto em que são discutidos. A Constituição Federal traz em seu bojo passagens em três incisos do artigo $5^{\circ}$ em que a garante nos seguintes termos
IV - é livre a manifestação do pensamento, sendo vedado o anonimato;
V - é assegurado o direito de resposta, proporcional ao agravo, além da indenização por dano material, moral ou à imagem;
IX - é livre a expressão da atividade intelectual, artística, científica e de comunicação, independentemente de censura ou licença.

\footnotetext{
${ }^{34}$ Disponível em: https://www.conjur.com.br/dl/voto-fachin1.pdf. Acesso em 20.03.2021.

${ }^{35}$ Disponível em: https://www.conjur.com.br/dl/voto-fachin1.pdf. Acesso em 20.03.2021.
} 
Pela leitura dos dispositivos é fácil notar que o campo de exercício da liberdade de expressão é amplo ao mesmo tempo em que sofre limitações implícitas e explicitas. Inicia com o postulado geral previsto no inciso IV, com a limitação do anonimato. No inciso V vislumbramos uma extensão da responsabilidade daquele que causa um dano ilícito a outrem. E, por fim, o inciso IX traz proteções específicas, incluindo a proibição da censura.

A existência no Brasil se deu até o advento da Carta de 19888, rotulada sob as mais variadas formas. Nos posicionamentos já esboçados pelo STF acerca do tema tem se decisões que oscilam a depender da espécie de censura que se está a analisar, podendo ser "privada", o que ocorre nos casos das biografias não autorizadas ou "governamental", tal como o fez neste último caso quando utilizou a expressão no julgamento da ADPF 130

[...] O corpo normativo da Constituição brasileira sinonimiza liberdade de informação jornalística e liberdade de imprensa, rechaçante de qualquer censura prévia a um direito que é signo e penhor da mais encarecida dignidade da pessoa humana, assim como do mais evoluído estado de civilização ${ }^{36}$.

No corpo da atual Constituição há que se lembrar da previsão do artigo 220, cujo parágrafo $2^{\circ}$ dispõe que "é vedada toda e qualquer censura de natureza política, ideológica e artística". Trata-se de uma disposição inserida no Capítulo dedicado à Comunicação Social (artigos 220 a 224) e que disciplina a liberdade do exercício da imprensa e que é relativizada pelos dispositivos que a compõem ${ }^{37}$.

Luís Roberto Barroso em artigo sobre o assunto pondera que as liberdades de informação e expressão são de caráter individual, relacionando-se como expressão dos direitos da personalidade, mas que não se pode prescindir da importância que a circulação das ideias exercem no regime democrático de direito, enquanto expressão do interesse público (2009).

\footnotetext{
${ }^{36}$ Disponível em: http://redir.stf.jus.br/paginadorpub/paginador.jsp?docTP=AC\&docID=605411. Acesso em 02.04.2021.

${ }^{37} \mathrm{O}$ parágrafo $1^{\circ}$ do artigo 220 é expresso ao estabelecer que "Nenhuma lei conterá dispositivo que possa constituir embaraço à plena liberdade de informação jornalística em qualquer veículo de comunicação social, observado o disposto no art. $5^{\circ}$, IV, V, X, XIII e XIV", ou seja, já lista as possibilidade constitucionais de limitação de tal exercício, que a exceções dos incisos XIII e XIV, já foram mencionadas no presente trabalho.
} 
A despeito do Supremo Tribunal Federal ter concluído pela inexistência de um direito à indenização pela pretensa existência de um direito ao esquecimento, o que reverbera no campo cível, entendemos que na seara do direito penal tal recontagem dos fatos, desde que condizente com as narrativas temporais em que restou apurado, constituir-se-ia numa situação de exercício regular de um direito ${ }^{38}$, concebido como

[...] o desempenho de uma atividade ou a prática de uma conduta autorizada por lei, que torna lícito um fato típico. Se alguém exercita um direito, previsto e autorizado de algum modo pelo ordenamento jurídico, não pode ser punido, como se praticasse um delito (NUCCI, 2020, p. 370).

Tal decisão pode ser compreendida à luz do artigo $5^{\circ}$, incisos XIII e XIV da Constituição Federal

XIII - é livre o exercício de qualquer trabalho, ofício ou profissão, atendidas as qualificações profissionais que a lei estabelecer;

XIV - é assegurado a todos o acesso à informação e resguardado o sigilo da fonte, quando necessário ao exercício profissional.

Ou seja, há para além da regulamentação legal da profissão, a norma constitucional que protege a liberdade do seu exercício, incluindo a atividade fim a que se destina a imprensa que é a prestação da informação, sem a qual restará esvaziada a sua própria finalidade. Como bem conclui Virgílio Afonso da Silva "uma imprensa livre e robusta tem um papel central na proteção e na promoção da democracia" (2021, p. 177).

Desta forma e com base num raciocínio sistematizado acerca do assunto, pontua Cezar Roberto Bitencourt que "o exercício de um direito, desde que regular, não pode ser, ao mesmo tempo, proibido pela ordem jurídica. Regular será o exercício que se contiver nos limites objetivos e subjetivos, formais e materiais impostos pelos próprios fins do Direito” (2020, p. 959).

Ainda nesta linha de raciocínio e com fundamento no ordenamento jurídico brasileiro, concluiu-se que o reconhecimento do exercício regular de direito afasta a possibilidade da conduta ser típica, impossibilitando repercussões cíveis, consoante prevê o artigo 65 do

${ }^{38}$ O Código Penal brasileiro dispõe no artigo 23 acerca das excludentes de ilicitude e elenca entre elas o "exercício regular de direito". 
Código de Processo Penal ao dispor que "faz coisa julgada no cível a sentença penal que reconhecer ter sido o ato praticado em estado de necessidade, em legítima defesa, em estrito cumprimento de dever legal ou no exercício regular de direito" (grifo nosso).

E nesta visão que torna-se muito delicada a defesa de um direito ao esquecimento quando se pretende exercer a liberdade de informar, ainda que compreenda fatos pretéritos. E nesta esteira indagamos e propomos a reflexão se o direito ao esquecimento não constituiria uma via implícita da instauração de um juízo de censura? Vejamos.

Admitir esquecimento é propor de certa forma o silêncio com as suas implicações e contradições, pois “[...] o próprio ato de falar exclui o que não foi dito, pois quando se diz algo - porque se elegeu para dizer - o que não foi dito vem em forma de silêncio, mas está em determinado lugar com seu significado" (RANGEL, 2018, p. 36).

Eis, portanto, algumas dificuldades de natureza prática e jurídica que o reconhecimento ou não da existência de um direito ao esquecimento, notadamente quando se trata de exercício da liberdade de expressão e informação impõe e que com certeza, num futuro próximo ainda demandará muitas construções no campo doutrinário e jurisprudencial.

\section{Conclusão}

$\mathrm{O}$ artigo apresentado buscou em linhas gerais discutir o direito ao esquecimento desde o surgimento da expressão na França e suas implicações nas decisões das Cortes daquele país até o Brasil, onde sequer há um consenso doutrinário quanto ao conteúdo e muito menos regulamentação legal.

Neste sentido, o tema fora analisado em conjunto com a relação que estabelece com alguns direitos fundamentais cuja natureza de direitos da personalidade pretende ser oponível erga omnes, mas sem esquecer que é do passado que o presente se estabelece e é no futuro que suas consequências serão melhor estabelecidas.

A memória precisa ser preservada, um povo jamais prescinde das narrativas dos fatos, quer a historicidade confirme ou não sua veracidade. Existir como discussão já seria justificativa para que tal fato fosse recontado com vistas à preservação de um interesse maior veiculado na própria função social da informação. 
Com base no que fora acima apresentado, os casos discutindo a existência de um direito ao esquecimento foram paulatinamente chegando aos Tribunais Superiores, em especial ao STJ e ao STF, existindo no primeiro decisões que entendem pela prevalência do interesse individual no resguardo da privacidade e intimidade e outras refutando-o.

No STF a questão foi apreciada com repercussão geral quando da análise do Recurso Extraordinário 101606, julgado em fevereiro de 2021 quando a Corte decidiu por 9 votos a 1 que o direito ao esquecimento é incompatível com o texto da atual Constituição, sem descurar do reconhecimento de que a prova de eventuais excessos ou abusos cometidos no exercício da liberdade de expressão e de informação deverão ser analisados em cada caso concreto, podendo ensejar a devida reparação.

\section{REFERÊNCIAS BIBLIOGRÁFICAS}

BARROSO, Luís Roberto. Liberdade de Expressão versus Direitos da Personalidade. Colisão de Direitos Fundamentais e Critérios de Ponderação. In: FARIAS, Cristiano Chaves de (Org.). Leituras Complementares de Direito Civil: o direito civil-constitucional em concreto. Editora JusPodvm: Salvador, 2009, p. 97-135.

BITENCOURT, Cezar Roberto. Tratado de Direito Penal. Volume 1. $26^{\mathrm{a}}$ ed. Editora Saraiva: São Paulo, 2020.

NUCCI, Guilherme de Souza. Manual de Direito Penal. 16 a ed. Editora Gen/Forense: Rio de Janeiro, 2020.

POLLAK, Michael. Memórias, esquecimento, silêncio. Revista Estudos Históricos, Rio de Janeiro, v. 2, n. 3. p. 3-15, 1989.

RANGEL, Paulo. Tribunal do júri: visão linguística, histórica, social e jurídica. $6^{\text {a }}$ edição. Editora Atlas: Rio de Janeiro, 2018.

SARLET, Ingo Wolfgang; MARINONI, Luiz Guilherme; MITIDIERO, Daniel. Curso de Direito Constitucional. $4^{\text {a }}$ ed. Editora Saraiva: São Paulo, 2017.

SILVA, Virgílio Afonso da. Direito Constitucional Brasileiro. Editora Universidade de São Paulo: São Paulo, 2021. 